\title{
Volcanoes as agents of past environmental change
}

\author{
J.P. Sadler a,), J.P. Grattan b \\ a The Unilersity of Birmingham, School of Geography, Edgbaston, Birmingham B15 2TT, UK \\ b The Unilersity of Wales, Institute of Earth Sciences, Aberystwyth, SY23 3DB., UK
}

\begin{abstract}
In recent years a sequence of papers has discussed the impact of volcanic eruptions upon global environments. Emphasis has been placed upon their potential role in depressing hemispheric temperatures and affecting global weather patterns. Many researchers have related ecological, environmental and historical phenomena to individual eruptions. However, the linking of spatially and temporally disparate phenomenon to eruption chronologies involves several levels of supposition and at each level in the argument greater potential for error arises. This paper examines critically a number of important issues that arise from these studies. How valid are the linkages that are drawn? Do they establish a dependent relationship or merely coincidence? The validity of linking volcanic activity with disparate spatial and temporal events in the climatic, historical and palaeoecological records is addressed. There can be little doubt that volcanoes have a great effect on proximal climates and environments, but their global impact is less well understood. The scale and magnitude of responses to large eruptions such as the historically notorious Tambora_1815.and Mt. Pinatubo_1991.is far from consistent. This paper urges the adoption of a more critical perspective when considering these issues.

Keywords: volcanoes; climate change; environmental change; temperature change; volcanic aerosols
\end{abstract}

\section{Introduction}

Volcanic eruptions have been invoked as a major causal factor in a range of studies that examine palaeoenvironmental processes. A necessarily vague temporal framework has been adopted in many such studies and this has been considered sufficiently accurate to allow speculation as to the environmental impact and magnitude of individual eruptions. There is an inherent danger in linking disparate and geographically dispersed palaeoenvironmental data to known eruptions. For example, a run of bad summers_Stommel and Stommel, 1979., an increase in sea ice off America_Catchpole and Hanuta, 1989., narrow rings in dendrochronological sequences _LaMarche and Hirschboek, 1984; Baillie, 1989, 1994; Scuderi, 1990., and neoglaciations_Porter, 1981, 1986; Nesje and Johannessen, 1992., can all be linked to temporally convenient climate forcing by volcanic aerosols. Speculation as to the likely effect of these eruptions on fauna and flora_Blackford et al., 1992; Charman et al., 1995. and human societies_Burgess, 1989; Kuniholm, 1990; Grattan and Gilbertson, 1994; White and Humphreys, 1994. may involve further supposition. A few notable exceptions provide more cautionary interpretations

_Mass and Portman, 1989; Zielinski et al., 1994, 1995..

The role of precursor climatic andror environmental conditions is frequently overlooked_Nicholls, 1988, 1990; Hansen and Lacis, 1990. and given the background level of volcanic activity outlined by McClelland et al.,_1989., it is valid to question whether the relationships established are fortuitous rather than dependant. Renfrew_1979: p. 582.summarised the problem succinctly:

" . . . it is necessary to recognise and discount the common tendency among archaeologists and historianswand other researchersxto assume a causal link between the distant and often widely separated events of which they have knowledge. An eruption here, a destruction there, a plague somewhere else- - all are too easily linked in hasty surmise."

This paper examines these issues and reviews critically the climatic, dendrochronological, historical and palaeoecological evidence that has sought to establish the role of volcanic eruptions as an agent for sudden, severe environmental change.

\section{Climate studies}

The potential climatic impact of large volcanic eruptions has stimulated much erudite discussion and speculation_Lamb, 1970; Mass and Schneider, 1977; Self et al., 1981; Kelly and Sear, 1984; Angell, 1985; Sear et al., 1987; Angell and Korshover, 1988; Chester, 1988; Bradley and Jones, 1992.. It is clear that eruptions which emit large volumes of sulphur, rather than particulate matter, may have clear climatic signatures and several have been observed to have depressed global temperatures_Rampino and Self, 1982, 1984; Devine et al., 1984; Rampino, 1988; Sigurdsson, 1990; Fig. $1 .$.

The assumption that climatically effective volcanic eruptions will result automatically in cooling at the Earth's surface is common in many studies that attempt to establish volcanic impacts upon the environment. However, recent modelling of the Mt. 
Pinatubo eruption in 1991, has indicated that the relationship between volatile emission and climate fluctuations is not a simple one _Bekki and Pyle, 1994. and is not solely related to the volume of sulphur emitted. The optical depth_Lacis et al., 1992. and residence time of the aerosol layer are also important. In some cases, atmospheric warming of both the stratosphere and troposphere _Lacis et al., 1992; Lary et al., 1994; Grattan and Sadler, 1997. is possible. The perturbation of the zonal wind which

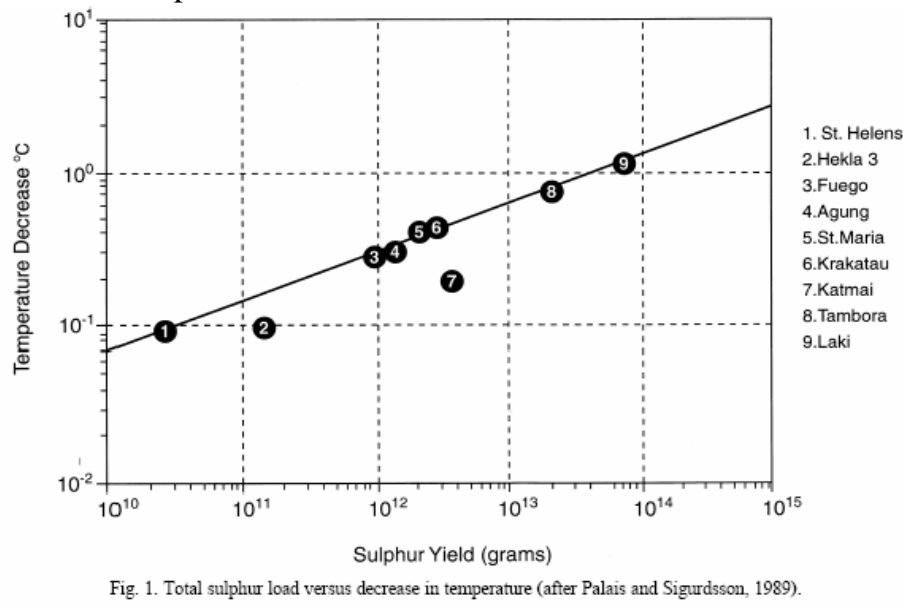

results from the regionally variable reduction in solar energy may also result in regional warming rather than cooling _Robock and Mao, 1992, 1995; McCormick et al., 1995.. This contradicts the assumption of cooling which is a fundamental tenet of many volcanorenvironment studies. Historic temperature records provide a suitable starting point for assessing whether volcanic aerosols have significantly affected global temperatures.

\subsection{Temperature records}

Where a reduction in surface air temperature has been observed or modelled, the scales of such reductions rarely support assumptions of related instances of temperature driven environmental change. Kelly and Sear_1984.assessed the climatic signal of eruptions between 1887 and 1980 and noted that the average depression in surface temperatures during the first twelve months after an eruption was between 0.3-0.48C. In a further study_Sear et al., 1987., the data set was extended to include marine and southern hemispheric data, and provided corroboratory evidence of slight, short term temperature perturbations. Bradley_1988.utilised an homogenous set of high quality gridded temperature data and observed short-lived drops in summer and autumn temperatures after major eruptions. He noted also that the effect decreased latitudinally away from the location of the eruption. None of the temperature fluctuations observed in these studies were in excess of the naturally occurring variability in surface air temperatures.

In a critical study, Mass and Portman _1989.

analysed the impact of nine volcanic events between 1883 and 1982 _Krakatau 1883, Tarawera 1886, Mt. PeleerSoufriererSanta Maria 1902, Ksudach 1907, Katmai 1912, Agung 1963, Awu 1966, Fuego 1974, and El Chicho'n 1982. and concluded that, whilst for the largest eruptions there was a suggestion of a post eruptive cooling of $0.38 \mathrm{C}$ in the composite temperature records, there was no obvious volcanic signal in atmospheric pressure and precipitation patterns _cf. Parker, 1985.. Of great significance in this study was the observation that surface temperature declines were underway already prior to several of the eruptions. The role of precursor climatic conditions are clearly important and cannot be ignored when suggesting that volcanic eruptions are responsible for environmental change_Rampino et al., 1982. It has been suggested that the El NiñorSouthern Oscillation_ENSO.circulation anomaly may obscure the surface temperature signal that is anticipated following large volcanic eruptions. Indeed, the removal of the ENSO signal from these data enhances the apparent impact of several of the larger eruptions_Parker, 1985.. A more direct link between the ENSO and volcanic eruptions has been noted by Handler_1986.who hypothesised that the modified heating patterns, caused by the injection of volcanic aerosols in high and low latitudes, results in the anomalous temperature gradients and sea level pressures for land and ocean that drive the ENSO. These conclusions have been challenged by some researchers. Nicholls_1988, 1990.observed the presence of a precursor signal that indicates the onset of an ENSO event in the months before the volcanic eruptions that were held responsible. Nicholls also noted the poor quality of the ENSO chronology used by Handler to establish a relationship between the climate phenomenon and the proposed forcing mechanism. Handler_1989., p. 247, has acknowledged that the hypothesis required further analysis to determine its validity, although a further study provided additional corroboratory data_Handler and Andsager, 1994.

The poor quality of chronologies that detail volcanic events and climatically notable phenomenon makes the pursuit of association between the two problematic. It is also important to note that "empirical analyses cannot prove a physical link between volcanic eruptions and surface climate but the statistical evidence strongly suggests such a link." _Sear et al., 1987, p. 366.. The empirical studies discussed above highlight two main points; firstly, that volcanic eruptions are associated with surface temperature anomalies that generally fall within the normal seasonal statistical variation_Angell, 1990.. Secondly, 
Table 1

Summer temperatures (degrees celius) at selected stations indicating the coldest years (Landsberg and Albert, 1974)

\begin{tabular}{llllll}
\hline Station & Period & Mean $\left({ }^{\circ} \mathrm{C}\right)$ & Standard deviation & Coldest temperature \\
\hline New Haven & $1780-1968$ & 20.9 & 0.9 & 18.4 & Year \\
Philadelphia & $1738-1972$ & 23.6 & 0.6 & 21.8 & 1816 \\
Edinburgh & $1771-1960$ & 18.3 & 1.3 & 12.9 & 1764 \\
Copenhagen & $1801-1970$ & 16.2 & 1.1 & 14.5 & 1840 \\
Wilno & $1781-1960^{\mathrm{a}}$ & 17.4 & 1.2 & 14.8 & 1928 \\
Berlin & $1756-1970^{\mathrm{a}}$ & 18.0 & 1.2 & 16.7 & 1732 \\
Vienna & $1775-1969$ & 19.2 & 1.2 & 11.4 & 1913 \\
Hohempeissenburg & $1771-1960$ & 14.0 & 1.3 & 18.7 & 1816 \\
Budapest & $1781-1970$ & 21.3 & 1.0 & 20.9 & 1953 \\
Rome & $1811-1969^{\mathrm{a}}$ & 23.5 & 0.9 & & \\
\hline
\end{tabular}

Indicates an interrupted sequence of years.

that while there exists a considerable amount of data that suggests that volcanic eruptions are related to historical temperature and circulation anomalies_Ellsaesser et al., 1986., serious questions remain as to the cause, scale and patterns of the cooling. One can illustrate this point by examining regional responses to the eruption of Tambora in 1815 , an event that is considered to have caused widespread cooling of 0.78C_cf. Harington, 1992. and precipitated the notorious 'year without a summer' in the United States_Stommel and Stommel, 1979, 1983.

\subsection{The Tambora eruption and Northern Hemisphere climate anomalies in 1816}

The summer of 1816 in the United States is notorious for frosts and snowfalls that ruined the harvest. Severe weather and frosts occurred on June 6th, which left three to six inches of snow on the ground; similar additional events occurred July 9th, August 21st and August 30th. The June of 1816 was recorded as the coldest ever in the city of New Haven,_CT, U.S.A.., but the temperatures recorded fall within the range of statistical normality _Landsberg and Albert, 1974.. This picture is less clear cut when other North American temperature records are considered and 1816 is seen to be typical of its decade rather than unique_Baron, 1992..

How typical were the experiences of New Haven for New England in general? Smith et al._1981.has constructed a temperature series for Maine that allows the climatic trend to be reconstructed with some accuracy. For the whole period 1785-1885, the climate of Maine was cool with short periods of warmer weather. In Maine, May frosts were not uncommon, and occasionally they were noted in June and August. June frosts occurred in 1778, 1794, 1797, 1800, 1807, 1816, 1817, 1832, and 1833. August frosts occurred in 1796, 1816, 1835 and 1836. With these conditions not uncommon, seeds were often planted indoors and transplanted after all chance of frosts appeared to have passed. Summer frosts then, were not isolated events on northeastern seaboard of the United States of America and their occurrence in 1816 need not be interpreted as indicating climate forcing by the Tambora eruption. This point is reinforced by a consideration of temperature data from North America and Europe as shown in Table 1. All the stations report temperatures below the average for 1816, most fall within two standard deviations of the mean and cannot be considered to be manifestations of extreme or freak weather. Hohenpeissenberg, Bavaria, which like New Haven experienced its coldest year, is a high altitude station, and one might expect it to be more sensitive to any climatic perturbation than low level stations. In Europe, the eruption of Tambora has also been held responsible for bad weather. A cold and wet summer was experienced in many parts of the British Isles, and in France, Germany, the Netherlands, and Switzerland_Wood, 1965; Post, 1977; Pfister, $1992 .$. To confuse this convenient picture of European stress, at the same time that eastern and central Europe suffered from poor weather and low harvest yields, northern Europe was experiencing mild, clement weather. Neumann_1990., noted that 1816 was not the year of temperature minima, and the Baltic states had a surplus of grain to export in the years that the climatic impact of the eruption was at its greatest potential, 1816-1817. Atmospheric circulation anomalies such as observed in Europe in 1816 _Kelly et al., 1984. may occur following volcanic eruptions _Lamb, 1970.and bring unseasonable cold and wet England_1765-1830._Manley, 1974..

weather to some areas, but clearly the same disruption will bring drier and warmer conditions to others _Kington, 1992; Lamb, 1992.and this possibility must be considered when modelling the palaeoenvironmental impact of volcanic eruptions.

The summer of 1816 in Europe was certainly memorable for the miserable weather experienced in many areas, but were the conditions truly exceptional 


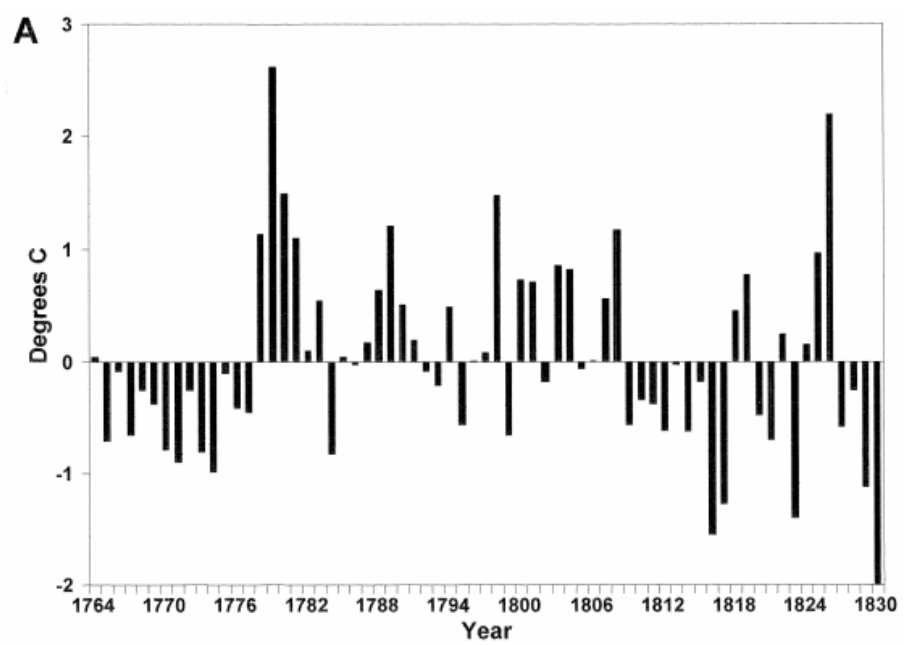

B

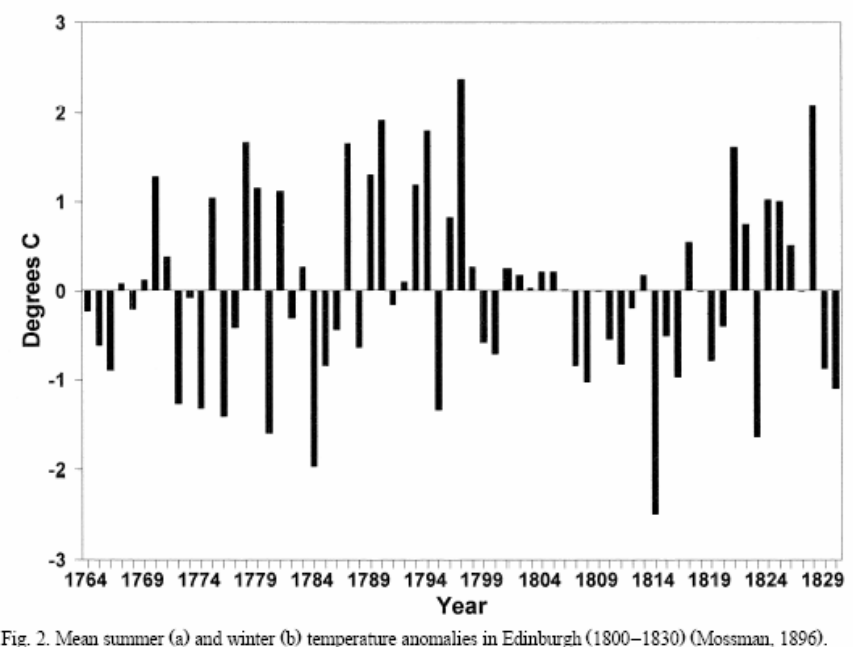

and of a degree for which it is reasonable to invoke an external forcing mechanism? In Scotland and England the winters of 1783-1784_the Laki Fissure eruption. and 1815-1816 cannot be considered exceptional when compared to the longer timeseries.

Many colder winters are indicated for which no external forcing mechanism has been invoked_Figs. 2 and 3.. The summer of 1815-1816 was cool, but should be interpreted in the light of a cool decade _Fig. 3.and other cold summers are indicated in 1823 and 1830, again for which no volcanic forcing mechanism has been invoked.

There is therefore a body of data that suggests that the summer of 1816 was not as exceptional as has been reported by some authorities. The bad weather phenomena reported cannot be indiscriminately assigned to the eruption of Tambora. The conditions experienced in some areas in 1816 appear to be the end of a series of poor years that started in the early 1810s_Jones and Bradley, 1992.. The suggestion_Lamb, 1970; Kelly and Sear, 1984.that low latitude eruptions such as Tambora will cause a southward displacement of north Atlantic circulation in the year following the eruption may account for some of these phenomena. It is extremely difficult, however, to isolate the climate signal from the background 'weather noise' _Hansen and Lacis, 1990; Lacis et al., 1992.. Groisman_1992. has addressed this question and identified some consistent weather patterns associated with nine large eruptions during the last two centuries_Table 2.. Mean surface air temperature anomalies indicate that Central Europe had warmer than usual winters after major eruptions, whereas Northeastern United States was subjected to a colder than average winters. Of importance here is the understanding that volcanic alteration of weather patterns can generate a regionally diverse series of conditions in which poor and clement weather may be experienced synchronously. This is in contrast to the assumption of an hemisperically homogenous deterioration that currently underlies many studies. An analysis of dendrochronological studies supports this picture of regional anomalies pointing to alteration in specific environmental conditions pertinent to particular trees in specific locations, rather than to climate deterioration on a wide scale.

\section{Dendrochronological evidence}

The physiological response of trees to environmental

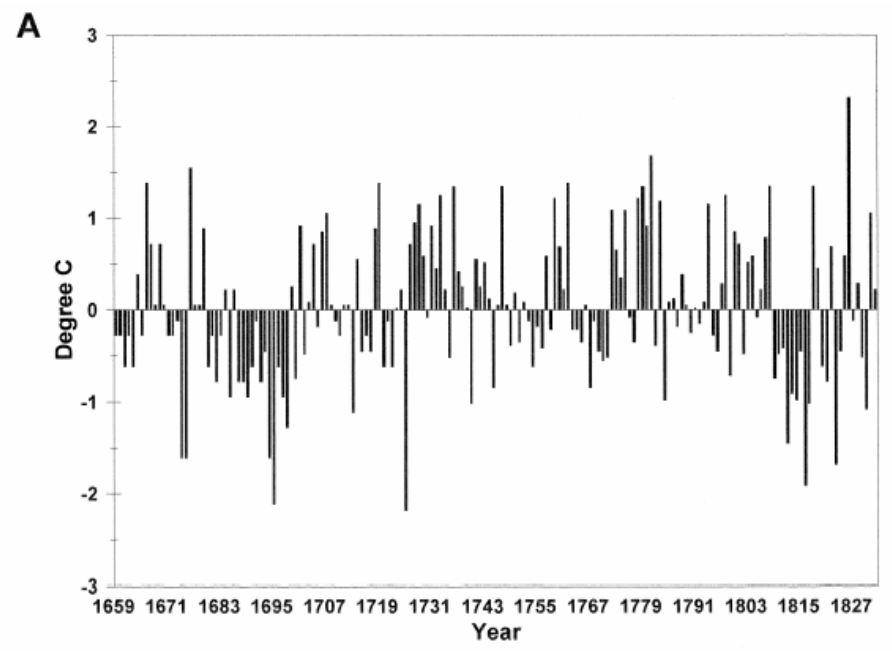

B

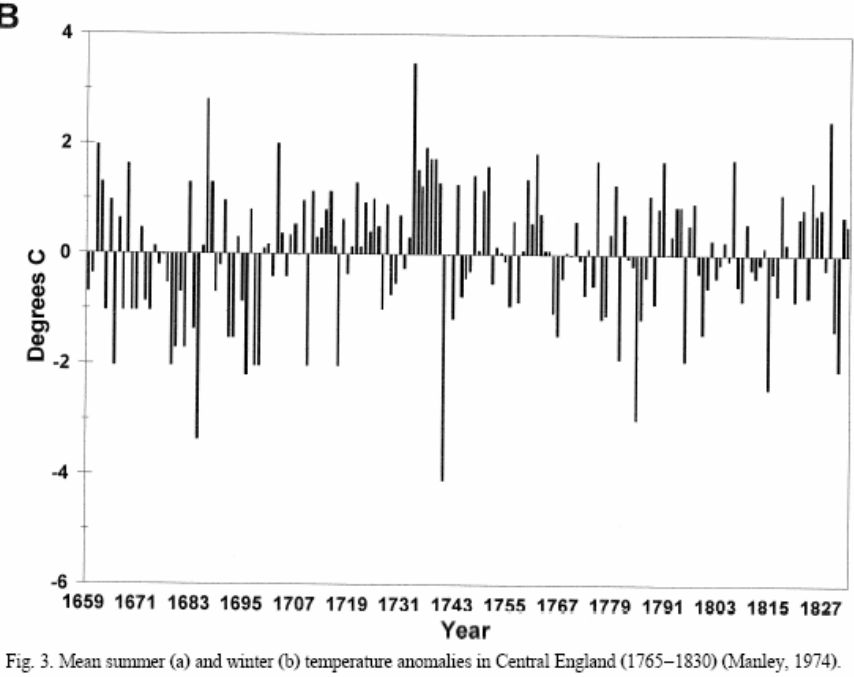


Table 2

Mean surface air temperature anomalies after large volcanic eruptions (after Groisman, 1992)

\begin{tabular}{lllll}
\hline Region & Winter & & Summer \\
\cline { 2 - 4 } \cline { 5 - 5 } & Sign of anomaly & $\begin{array}{l}\text { Sign of anomaly } \\
\text { significant at } \\
95 \% \text { level }\end{array}$ & $\begin{array}{c}\text { Sign of the anomaly } \\
\begin{array}{l}\text { Sign of anomaly } \\
\text { significant at } \\
95 \% \text { level }\end{array}\end{array}$ \\
\hline Central Europe (part of Russia) & + & Yes & - & Yes \\
Ukraine & + & No & - & Yes \\
Westem Europe (excl. the Mediterranean region) & + & No & - & No \\
Northeastem United States & - & No & - & Yes \\
\hline
\end{tabular}

Table 3

Largest temperature anomalies and trends in Fennoscandia (after Briffa et al., 1990)

\begin{tabular}{llll}
\hline $\begin{array}{l}\text { Positive } \\
\text { Anomaly }\left({ }^{\circ} \mathrm{C}\right)\end{array}$ & Year & $\begin{array}{l}\text { Negative } \\
\text { Anomaly }\left({ }^{\circ} \mathrm{C}\right)\end{array}$ & Year \\
\hline Individual summers & \multicolumn{3}{l}{} \\
2.07 & 1761 & -1.65 & 1139 \\
2.05 & 1831 & -1.58 & 1109 \\
1.99 & 1703 & -1.57 & 961 \\
1.71 & 1937 & -1.53 & 800 \\
& & & \\
Twenty year mean & $1158-1177$ & -0.93 & $1127-1146$ \\
0.78 & $1748-1767$ & -0.73 & $795-814$ \\
0.79 & $749-768$ & -0.65 & $1601-1620$ \\
0.67 & $1087-1106$ & -0.55 & $848-867$ \\
0.52 & $1551-1570$ & -0.53 & $1344-1363$ \\
0.49 & & & \\
& & & $1108-1157$ \\
Fifty year mean & $1152-1201$ & -0.58 & $1576-1625$ \\
0.35 & $1403-1452$ & -0.42 & $780-814$ \\
0.34 & $1750-1799$ & -0.34 & $1867-1916$ \\
0.33 & $719-768$ & -0.31 & $1345-1394$ \\
0.29 & $926-1011$ & -0.23 & \\
0.27 & &
\end{tabular}

stress is recorded in their annual growth

increment. Studies of ring-width_LaMarche, 1974;

LaMarche et al., 1984; Baillie, 1988., ring-colour

_Filion et al., 1986., isotopic ratio _Epstein and

Krishnamurthy, 1990., damaged annual rings

_LaMarche and Hirschboek, 1984.and late and

early-wood density _Conkey, 1986; Graumlich and

Brubaker, 1986; Briffa et al., 1988a,b, 1990; Scud-

eri, 1990., allow the reconstruction of the macro and

micro environmental influences on a tree's location.

The longevity of particular tree species, the survival

of others in fossil form and their wide latitudinal and

geographical distribution, permits the reconstruction

of climatic change _LaMarche, 1974; Fritts et al.,

1979, 1981. and has encouraged attempts to assess

of the climatic significance of individual eruptions.

European dendrochronological studies have reconstructed

long term temperature trends in some

detail, but largely fail to record an anomalous growth

year in either 1783-1784 or 1815-1816_Briffa et

al., 1988a.. This work identified several years where significant departure from the mean occurred_Table 3. but these are not associated with volcanic forcing of climate. For example, 1782 is recorded as a poor year in Scandinavia, and this was a year of crop failure in Britain, but a significant volcanic eruption is not recorded in the ring sequence for this year _Hughes et al., 1984.. In the Finnish tree-ring record the summer of 1783 was recorded by narrow rings, caused by extremely high temperatures and drought rather than by cool wet conditions. Recent research _Briffa and Schweingruber, 1992., has indicated that the summer of 1783 was warmer than the 1951-1970 mean.

The work of Schove_1950, 1954.similarly fails to indicate a significantly narrow tree-ring for 1816 but confirms the instrumental data discussed above, that the 1810s saw the beginning of a short cool period in Europe_Briffa et al., 1988a,b; Briffa and Schweingruber, 1992; Graybill and Shiyatov, 1992.. Briffa et al. _1990., reconstructed Fennoscandian summer temperatures for the past 1400 years, based on raw mean ring widths and the maximum latewood density of conifers from the Tornetr" ask region of northern Sweden_Table 4.. Growing at high latitudes this record is sensitive to climate change and is worth considering in detail. Clearly none of the worst individual summers in Fennoscandia correlate with acid peaks in the Greenland ice core _Hammer et al., 1980, 1981.. Equally neither the worst twenty years nor the worst fifty years in their reconstruction can be linked to known volcanic activity and to imply a volcanic agency for these events therefore is doubtful. The tree-ring evidence suggests that Europe experienced cold conditions between 1810-1817 and 1832-1838 and slight warming between 18191828 and 1868-1875.

Many North American chronologies present a broadly similar picture to that noted in Europe of cooling in the early 1800s, and warming from the mid 1800s_LaMarche and Stockton, 1974; LaMarche et al., 1984; Jacoby et al., 1985, 1988; D’Arrigo and Jacoby, 1992.. In continental locations such records of climatic conditions are widely replicated; the reconstruction of Villalba_1990.climate in northern Patagonia also indicates a cold period in the early 
Narrow and light rings in Northern Hemisphere dendrochronological sequences that are coincident with the Laki fissure eruption in 1783 and Tambora in 1815

\begin{tabular}{|c|c|c|}
\hline Region & Laki 1783 & Tambora 1815 \\
\hline Europe: N-S transect Greece to Finland (Briffa et al., 1988a,b) & $\mathrm{NO}$ & $\mathrm{NO}$ \\
\hline North and central (Briffa et al., 1990, 1992; Briffa and Schweingruber, 1992) & NO & NO \\
\hline Russia N. Urals (Graybill and Shiyatov, 1992) & NO & NO \\
\hline Asia: Himalaya (Hughes, 1992) & NO & Cold spring \\
\hline China (Wu, 1992) & NO & NO \\
\hline USA: North west (Fritts and Shao, 1992) & NO & NO \\
\hline Great Plains (Meko, 1992) & NO & $\mathrm{NO}$ \\
\hline Califormia, Nevada (LaMarche and Hirschboek, 1984) & NO & YES \\
\hline Sierra Nevada (Scuderi, 1990) & YES & YES \\
\hline North East (Cook et al., 1992) & NO & Drought (but $>$ ENSO event) \\
\hline Alaska (Oswalt, 1957) & YES & NO \\
\hline Canada (D'Anrigo and Jacoby, 1992) & NO & YES \\
\hline Quebec (Filion et al., 1986) & YES & YES \\
\hline N. Quebec (Jacoby et al., 1988) & NO & YES \\
\hline
\end{tabular}

1800s, and warming since 1850. In North America limited tree-ring evidence for a poor summer in 1816 can be found and many chronologies present contradictory evidence for environmental stress in eruption years_Jacoby and Ulan 1982; Jacoby et al., 1985, 1988; Conkey, 1986; Graumlich and Brubaker, 1986; Cleaveland, 1992; Jacoby and D’Arrigo, 1989, 1992; Fayle et al., 1992; Lough, 1992.. In most cases the response of each chronology was conditioned by environmental factors particular to each tree's location rather than climatic change on a large scale.

Some chronologies claim to have identified a persistent volcanic signal in the tree ring record but these are necessarily hampered by incomplete eruption chronologies and by the poor relationship between the different studies that pursue this theme. LaMarche and Hirschboek_1984.identified 17 frost rings in the period $2035 \mathrm{BC}-1884 \mathrm{AD}$, and suggested that these indicated climatic stress caused by volcanic eruptions. Attractive as this work is, their correlations linking frost damage to volcanic events are highly questionable. Not all damaged rings are associated with years of volcanic eruptions. Major eruptions, among them Laki and Tambora do not appear to have caused frost damage whereas relatively minor eruptions appear to have done so _Parker, 1985.. If one accepts that sulphur content is a main

Table 4

Years with a departure greater than $1{ }^{\circ} \mathrm{C}$ from the $1951-1970$ mean. (after Briffa et al., 1988a,b)

\begin{tabular}{|c|c|c|c|c|c|}
\hline \multicolumn{2}{|c|}{ United kingdom } & \multicolumn{2}{|c|}{ Scandinavia } & \multicolumn{2}{|c|}{ Central Europe } \\
\hline- & + & - & + & - & + \\
\hline 1782 & & $\begin{array}{l}1772 \\
1782 \\
1790\end{array}$ & 1761 & & \\
\hline
\end{tabular}

1799

1812

1816

1829

1829

1814

1816

1831

1838

1852

1860

1864

1867

1868 factor in determining the climatic impact of eruptions then this point is significant because Laki and Tambora would have been the most effective volcanic agents of climate change in the Holocene. It must be stressed, however, that present knowledge of prehistoric eruptions is very limited.

Scuderi_1990, 1992., linked a physiological response in trees to the presence of volcanic aerosols in the upper atmosphere, and a subsequent increase in optical depth, and decrease in solar receipts at the surface_Baldwin et al., 1976; Mass and Schneider, 1977; Self et al., 1981; Pollack, 1981; Deepak and Newell, 1982; Rampino and Self, 1982, 1984; Sato et al., 1993.. Ninety-one severe ring width events are observed in the period 500 BC-1980 AD. Forty-six of these correlate with volcanic eruptions. As with the work of LaMarche and Hirschboek_1984.no narrow rings are associated with eruptions that are known to have emitted large amount of acidic volatiles, such as Tambora or Laki. The failure of the tree ring minima to record these events suggests that the technique is not infallible as a proxy record of volcanic eruptions_cf. Pyle, 1992..

The occurrence of 'light rings' in the black spruce tree_Picea mariana.growing at the tree-line in northern Quebec, has been taken to indicate a shortened growing season_Filion et al., 1986.. Sixty five light-rings were identified in the period AD 13081982, of which 43 were correlated with volcanic eruptions identified by Simkin et al._1981.with a Volcanic Explosivity Index_VEI.of )4. Light-rings occurred in 1784 and in 1816 and 1817 that suggests that the eruption of the Laki fissure and Tambora may be recorded by this tree-ring study. Similar to other tree-ring studies the occurrence of this diagnostic feature is sporadic and not all the trees sampled have produced light-rings in eruption years. However, the sporadic occurrence of the marker ring makes the simple correlation of an anomalous narrow tree-ring with a volcanic eruption an insufficient indication that one may be dependent on the other. The examples discussed above highlight the pitfalls involved in assessing the palaeoclimatic impact of any volcanic eruption. Each demonstrates the role and importance of the local environment in conditioning the response to external environmental stress. The environmental record of stress in eruption years is far from consistent. It is relevant that eruptions such as Laki 1783 and Tambora 1815, which are 
thought to be climatically significant failed to trigger a consistent response in many of the chronologies _Table 5.and that the intensively studied Mt Pinatubo eruption caused warming in some areas of the northern hemisphere_Robock and Mao, 1992, 1995.. If one accepts that there are difficulties in isolating global climate responses to individual eruptions in climatically sensitive organisms, then doubt can be cast upon the hypothesis that the cumulative impact of several eruptions upon can affect climatically sensitive phenomena such as glaciers?

\section{The cumulative effect of volcanic eruptions}

There is some support from decadal studies of glaciers_e.g., Porter, 1981, 1986.and tree rings _Scuderi, 1990, 1992.to indicate that cumulative effects of volcanic aerosol are important in forcing climatic variations. Nesje and Johannessen_1992. have considered this question in detail and suggested that volcanic aerosol loading of the stratosphere throughout the Holocene has been a major factor influencing climate and hence glacier advance. The implicit assumption is that the Greenland ice-core evidence gives an overall assessment of the numbers of eruptions_with large sulphur components.in the world since Late Glacial times. They produced a correlation between the acidity record from the Cre^ate and Camp Century ice cores and global glacier fluctuations and solar insolation. The resultant coefficient for acidity against glacier advances is very strong_rs0.71.and when the insolation data is added it rises to a very high level_rs0.90.. There are problems with such an approach in that it does not utilise ice-core data from elsewhere in the world_e.g., Petit et al., 1990; Mosley-Thompson, 1992; Peel, 1992; Tarussov, 1992; Thompson, 1992.. Perhaps more importantly, however, work on major eruptions has indicated that their impact is shortlived. For there to be significant volcanic effects on low frequency temperature changes, explosive eruptions of the magnitude studied here would have to recur in short intervals_-3 years.and there is no evidence that this has happened over the last 100 years_Bradley, 1988.. Similarly, Self et al._1981, p. 41. noted that "temperatures do not remain depressed for a longer period after a series of closelytimed eruptions than after single events', Once the background levels of acidity are removed from the record, correlations are considerably less impressive _rsy0.23._Crowley et al., 1993.. These results corroborate the conclusions of Wigley_1991.who suggests that the pooled effect of frequent eruptions Table 6

The expected global enuption frequency every thousand years. (Data from McClelland et al., 1989), the Volcanic Explosivity Index (VEI) (Simkin et al., 1981; Newhall and Self, 1982) ranks volcanic eruptions on volcanological criteria to assess their magnitude, intensity, dispersive power and destructiveness. The scale of an eruption is ranked from $1-8$, with 8 being the largest

\begin{tabular}{ll}
\hline & Enuption frequency (per 1000 years) \\
\hline 1 & 12,000 \\
2 & $12-16,000$ \\
3 & $4-5,000$ \\
4 & 600 \\
5 & 65 \\
6 & 25 \\
7 & $1-5$ \\
\hline
\end{tabular}

may have been overestimated. Volcanic activity is not the sole external forcing mechanism operating upon the earth's environment and the potential of these to cause the phenomena described should not be lightly dismissed_cf. Eddy, 1992; Stuiver and Braziunas, 1992.

\section{Discussion}

It is clear from data discussed above, that while a climatic signal may be detectable following a volcanic eruption, the scale of temperature fluctuations observed fall within the normal range and is not extreme. Studies of environmental phenomena observed to occur following major volcanic events suggest that any environmental impacts are spatially heterogeneous rather than homogenous. It follows on from this that linking disparate spatial events to large eruptions has associated difficulties. Work on erupJ. tion frequencies in the Twentieth century _McClelland et al., 1989; Table 6., gives a total expected eruption rate of approximately 30,000 per 1000 years, many of which have gone unrecorded_Simkin et al., 1981.. Baillie_1991, p.12. highlights cleverly one the problems with his dual concepts of suck in and smear out. He notes that the "specification of a 
Table 7

Phenomena associated with Irish ring-width minima (Data from Bryson and Goodman, 1980; Stothers and Rampino, 1983a,b; Pang et al., 1987, 1988, 1989; Baillie, 1988, 1989, 1994; Baillie and Munro, 1988; Burgess, 1989; Kumiholm, 1990; Wamer, 1990)

\begin{tabular}{|c|c|}
\hline Irish oak ring width minima & Associated phenomena \\
\hline $1159 \mathrm{BC}$ & $\begin{array}{l}\text { The Hekla } 3 \text { eruption. Greenland acidity peak, } 1120 \pm 50 \mathrm{BC} \text {. } \\
\text { Abandonment of the Strath Of Kildonan. Late } 12 \text { th Century BC. } \\
\text { Movement of the 'Sea People' Ca. } 1200 \mathrm{BC} \text {. } \\
\text { Fall of Mycenae. Ca. } 1200 \mathrm{BC} \text {. } \\
\text { Plague in Ireland } 1180-1131 \mathrm{BC} \text {. } \\
\text { Hittites leave Anatolian Plateau. } 13 \text { th Century BC. } \\
\text { Libyan peoples migrate towards Egypt. Ca. } 1200 \mathrm{BC} \text {. } \\
\text { Catastrophic flooding in Hungary. Ca. } 1200 \mathrm{BC} \text {. } \\
\text { Rise in level of the Caspian Sea. Ca. } 1200 \mathrm{BC} \text {. } \\
\text { Wide tree rings in Turkey. } 1159 \mathrm{BC} \text {. } \\
\text { Deepening of lakes in Turkey. } 1200-1100 \mathrm{BC} \text {. } \\
\text { Lowered snowline in Norway. Ca. } 1200 \mathrm{BC} \text {. } \\
\text { Crop failure in China. }\end{array}$ \\
\hline $207 \mathrm{BC}$ & $\begin{array}{l}\text { Unknown eruption. Greenland acidity peak. } 210 \pm 30 \mathrm{BC} \text {. } \\
\text { Irish murrain of cattle. } 210-200 \mathrm{BC} \text {. } \\
\text { Stars invisible in China. } 208 \mathrm{BC} \text {. } \\
\text { Chinese famines. } 207-204 \mathrm{BC} \text {. } \\
\text { Chinese dynastic change. } 202 \mathrm{BC} \text {. } \\
\text { Frost ring event. } 206 \mathrm{BC} \text {. }\end{array}$ \\
\hline $540 \mathrm{AD}$ & $\begin{array}{l}\text { Unknown eruption. Greenland acidity peak. } 516 \pm 4 \mathrm{AD} \text {. } \\
\text { European Mystery Cloud. } 536 \mathrm{AD} \text {. } \\
\text { Chinese atmospheric disturbance } 540 \mathrm{AD} \text {. }\end{array}$ \\
\hline
\end{tabular}

dendrochronological horizon tends to suck in loosely-dated archaeological, environmental and even ancient-historical information- the dated event being used to explain a wide spread of previous observations”. The converse can also be true and "truly synchronous events in the past may have gone unrecognised because the dating- mostly radiocarbon based- has smeared the 'event' into a 'period", '_op cit, 1991, p.12.. However, caution is also needed when specific dendrochronological dates are used to link spatially disparate phenomena_Table 7.. This kind of association is at best only indicating coincidence in time and requires further critical evaluation. Correlations between tree-ring minima and volcanic eruptions must specify the mechanism by which the eruption was able to trigger a response in the growing tree. Grattan_1994.and Grattan and Gilbertson _1994.have argued persuasively for acid deposition upon acid sensitive environments being a contributory cause of such phenomena. Associations such as these, however, must be based on correlations with ice-core acidity records_Hammer, 1977, 1984; Hammer et al., 1980, 1981.. Calculation of the complete ionic balance and isolation of the SO2ysignal by the 4 use of statistical methods_Mayewski et al., 1993; Zielinski et al., 1994., the location of identified tephra in particulate meltwater-extracts_e.g., Fiacco et al., 1994., has enabled researchers to relate the electrical conductivity and SO2- timeseries in ice 4 cores to known eruptions_Zielinski et al., 1995., thereby improving chronological resolution. Such work must also be linked with estimates of volcanic degassing _Devine et al., 1984; Palais and Sigurdsson, 1989.. Only then may it be possible to measure effectively the ability of an eruption to force such climatic change.

There are difficulties of relating eruption chronologies to the archaeological and palaeoecological records even where one is dealing with a known tephra horizon_Lotter and Birks, 1993.. It is not enough to fit a the local picture derived from single events into the wider context of a global change hypothesis. Similarly, works of synthesis defining global hypotheses tend to overlook the detailed local variations that may have occurred in the past. The undoubted improvement in eruption chronologies in terms of temporal and spatial coverage must go hand in hand with detailed studies examining the evolution and distribution of volcanic aerosols after major events. Factors such as the amount of sulphur gases emitted and micro-physical processes of particle growth and coagulation is known to be important _Pinto et al., 1989.. Moreover, recent modelling indicates that the residence time for aerosols after large eruptions is no greater than with smaller events, because feedback processes permit aerosols to grow quickly and fall out faster_Pyle et al., 1997.. This is of some significance for assessing the impact of past eruptions, where global temperatures are thought to respond to SO2y in a near linear fashion. There is 4 
considerable scope for further work dealing with the local impacts of particular volcanic events coupled with research into the cumulative effect of eruptions on the longer time scales of decades, centuries and millennia.

\section{Conclusion}

There is little doubt that volcanic activity has a climatic effect but the historical temperature record indicates a surface cooling that in most cases falls within expected annual variation. When these data are considered closely the patchy nature of change is emphasised. Instrumental and tree-ring data fail to demonstrate a coherent and consistent response to volcanic climate-forcing. What is clear is that volcanic eruptions are capable of exerting a profound influence upon environmental systems that are sensitive to such forcing. Hence trees that are particularly stressed in respect of one or more aspects of their environment may respond negatively to a slight increase in atmospheric optical depth, whilst trees that are not sensitive and may be considered to be complacent in respect of their environment fail to record eruption years as significant. It is the sensitivity of the tree rather than the effectiveness of the volcanic eruption that is being indicated in such a case and it is the failure to recognise this that undermines many dendrochronological studies. Instrumental data also indicates a disparate rather than homogenous response to volcanic forcing of weather. An analysis of many of the studies above makes it clear that any attempt to extrapolate a regional or hemispheric response to volcanic eruptions from data that may be recording very local response is problematic. The real power of studies that use volcanic eruptions as an agent of past environmental change will lie in the construction of models of environmental response that are based on a synthesis of many studies. These studies must emphasise not only the scale and magnitude of the eruption, but also the sensitivity of the responding phenomena to the, often slight, degree of forcing applied.

\section{Acknowledgements}

This research for this paper has been supported by funding from the Leverhulme Trust_JPS.and SERC _JPG.. The work has benefitted from discussion with numerous people including: Jeffrey Blackford, Paul Buckland, Andrew Dugmore, Kevin Edwards, David Gilbertson, and Tom McGovern. Thanks are due to drawing office in Birmingham for rapidly redrawing Fig. 1. Andrew Moss commented on an early draft of the paper and the constructive suggestions of two anonymous referees are gratefully acknowledged.

\section{References}

Angell, J.K. Surface temperature changes following the six major volcanic episodes between 1780 and 1980, 1985. Journal of Climate and Applied Meteorology 24, 937-951. Angell, J.K., 1990. Variations in global tropospheric temperature after adjustment for the El Nin o influence, 1958-89. Geophysical Research Letters 17, 1093-1096.

Angell, J.K., Koshover, J., 1988. Impact of El Nin o on the delineation of tropospheric cooling due to volcanic eruptions. Journal of Geophysical Research 93_D4., 3697-3704.

Baillie, M.G.L., 1988. Tree-Ring Dating and Archaeology. Croom Helm, Canberra.

Baillie, M.G.L., 1989. Hekla 3: how big was it? Endeavour 13 _., 78-81.

Baillie, M.G.L., 1991. Suck in and smear, two related chronological problems for the 90's. Journal of Theoretical Archaeology 2, 12-16.

Baillie, M.G.L., 1994. Dendrochronology raises questions about the nature of the AD536 dust-veil event. The Holocene 4 _2., 212-217.

Baillie, M.G.L., Munro, M.A.R., 1988. Irish tree rings, santorini and volcanic dust veils. Nature 332, 344-346.

Baldwin, P., Pollack, J.B., Summers, A., Toon, O.B., Sagan, C., Van Camp, W., 1976. Stratospheric aerosols and climatic change. Nature 263, 551-555.

Baron, W.R., 1992. 1816 in perspective: the view from the Northeastern United States. In: Harington, C.R. Ed.., The Year Without a Summer? World Climate in 1816. Canadian Museum of Nature, Ottawa, pp. 124-144.

Bekki, S., Pyle, J.A., 1994. A 2-dimensional modeling study of the volcanic eruption of Mount Pinatubo. Journal of Geophysical Research-Atmospheres 99_D9., 18861-18869.

Blackford, J.J., Edwards, K.J., Dugmore, A.J., Cook, G.T., Buckland, P.C., 1992. Hekla-4: icelandic volcanic ash and the mid-holocene Scots Pine decline in northern Scotland. The Holocene 2 3., 260-265.

Bradley, R.S., 1988. The explosive volcanic eruption signal in northern hemisphere continental temperature records. Climatic Change 12, 221-243.

Bradley, R.S., Jones, P.D., 1992. Records of explosive volcanic eruptions over the last 500 years. In: Bradley, R.S., Jones, P.D._Eds.., Climate Since AD 1500. Routledge, London, pp. 606-622.

Briffa, K.R., Schweingruber, F.H., 1992. Recent dendroclimatic evidence of northern and central European summer temperatures. In: Bradley, R.S., Jones, P.D._Eds.., Climate Since AD 1500. Routledge, London, pp. 366-392.

Briffa, K.R., Jones, P.D., Pilcher, J.R., Hughes, M.K., 1988a. Reconstructing summer temperatures in northern Fennoscandinavia back to A.D. 1700 using tree-ring data from Scots Pine. Arctic and Alpine Research 20 _4., 295-385.

Briffa, K.R., Jones, P.D., Schweingruber, F.H., 1988b. Summer temperatures over Europe: a reconstruction from $1750 \mathrm{AD}$ based on maximum latewood density indices of conifers. Quaternary Research 30, 36-52.

Briffa, K.R., Bartholin, T.S., Eckstein, D., Jones, P.D., Karle'n, W., Schweingruber, F.H., Zetterburg, P., 1990. A 1400-year tree-ring record of summer temperatures in Fennoscandia. Nature 346, 434-439.

Briffa, K.R., Jones, P.D., Schweinguber, F.H., 1992. Tree-ring density reconstructions of summer temperature patterns across western Northern America since 1600. Journal of Climate 5, 735-754.

Bryson, R.A., Goodman, B.M., 1980. Volcanic activity and climatic changes. Science 207, 1041-1044.

Burgess, C., 1989. Volcanoes, catastrophe and the global crisis of the late second millenium BC. Current Archaeology 117, 325-329.

Catchpole, A.J.W., Hanuta, I., 1989. Severe summer ice in Hudson Strait and Hudson Bay following major volcanic eruptions, 1751 to 1889 A.D. Climatic Change 14, 61-79. 
Charman, D.J., Grattan, J.P., West, S., 1995. Environmental response to tephra deposition in the Strath of Kildonan, northern Scotland. The Journal of Archaeological Science 22 _6., 799809.

Chester, D.K., 1988. Volcanoes and climate: recent volcanological perspectives. Progress in Physical Geography 12 _1., 1-35. Cleaveland, M.K., 1992. Volcanic effects on Colorado plateau douglas fir-tree rings. In: Harington, C.R. Ed.., The Year Without a Summer? World Climate in $181 \overline{6}$. Canadian Museum of Nature, Ottawa, pp. 115-123.

Conkey, L.E., 1986. Red Spruce tree-ring widths and densities in Eastern North America as indicators of past climate. Quaternary Research 26, 232-243.

Cook, E.R., Stahle, D.W., Cleaveland, M.K., 1992. Dendroclimatic evidence from eastern North America. In: Bradley, R.S., Jones, P.D. Eds.., Climate since A.D. 1500. Routledge, London, pp. 331-348.

Crowley, T.J., Criste, T.A., Smith, N.R., 1993. Reassessment of Cre^te_Greenland.ice core acidityrvolcanism link to climate change. Geophysical Research Letters 20 _3., 209-212. D’Arrigo, R.D., Jacoby, G.C., 1992. Dendroclimatic evidence from northern North America. In: Bradley, R.S., Jones, P.D. _Eds.., Climate Since AD 1500. Routledge, London, pp. 296312.

Deepak, A., Newell, R.E._Eds.., Mt. St. Helens eruptions of 1980. Atmospheric effects and potential climatic impact... NASA SP, p. 458

Devine, J.D., Sigurdsson, H., Davis, A.N., Self, S., 1984. Estimates of sulfur and chlorine yield to the Atmosphere from volcanic eruptions and potential climatic effects. Journal of Geophysical Research 89, 6309-6325.

Eddy, J.A., 1992. Before Tambora: the sun and climate. In: Harington, C.R._Ed.., The Year Without a Summer. Canadian Museum of Nature, Ottawa, p. 11.

Ellsaesser, H.W., MacCracken, M.C., Walton, J.J., Grotch, S.L., 1986. Global climate trends as revealed by recorded data. Reviews of Geophysics 24, 745-792.

Epstein, S., Krishnamurthy, R.V., 1990. Environmental information in the isotopic record in trees. Philosophical Transactions of the Royal Society of London A 330, 427-439.

Fayle, D.C., Bentley, C.V., Scott, P.A., 1992. How did treeline white spruce at Churchill Manitoba, respond to conditions around 1816. In: Harington, C.R. Ed.., The Year Without a Summer. Canadian Museum of Nature, Ottawa, pp. 281-290. Fiacco, R.J., Thordarson, Th., Germani, M.S., Self, S., Palais, J., Whitlow, S., Groutes, P., 1994. Atmospheric aerosol loading and transport due to the 1783-84 Laki eruption in Iceland, Interpreted from ash particles and acidity in the GISP2 ice-core. Quaternary Research 42 _3., 231-240.

Filion, L., Payette, S., Gauthier, L., Boutkin, Y., 1986. Light rings in subarctic conifers as a dendroecological tool. Quaternary Research 26, 272-279.

Fritts, H.C., Lofgren, R.G., Gordon, G.A., 1979. Variations in climate since 1602 as reconstructed from tree-rings. Quaternary Research 12, 18-46.

Fritts, H.C., Lofgren, R.G., Gordon, G.A., 1981. Reconstructing seasonal to century time scale variations in climate from tree ring evidence. In: Wigley, T.M.L., Ingram, M.J., Farmer, G. _Eds.., Climate and History: Studies in Past Climates and their Impact on Man. C.U.P., pp. 139-161.

Fritts, H.C., Shao, X.M., 1992. Mpaaing climate sing tre-rings from western North America. In: Bradley, R.S., Jones, P.D.

_Eds.., Climate since A.D. 1500. Routledge, London, pp. 269-295.

Grattan, J.P., 1994. Land abandonment and Icelandic volcanic eruptions in the late 2nd millennium. In: Sto “tter, J., Wilhelm, F._Eds.., Environmental change in Iceland. Mu“nchener Geographische Abhandlungen B 12, pp. 111-132.

Grattan, J.P., Gilbertson, D.D., 1994. Acid-loading from Icelandic tephra falling on acidified ecosystems as a key to understanding archaeological and environmental stress in northern and western Britain. Journal of Archaeological Science 21 6., 851-859.

Grattan, J.P., Sadler, J.P., 1997. Regional warming of the lower atmosphere in the wake of volcanic eruptions: the role of the Laki fissure eruption in the hot summer of 1783. Quarterly Journal of the Geological Association.

Graumlich, L.J., Brubaker, L.B., 1986. Reconstruction of annual temperature_1590-1979.for Longmire Washington derived from tree-rings. Quaternary research 25, 223-234.

Graybill, D.A., Shiyatov, S.G., 1992. Dendroclimatic evidence from the northern Soviet Union. In: Bradley, R.S., Jones, P.D.

Eds.., Climate Since AD 1500. Routledge, London, pp. 393$\overline{4} 14$.

Groisman, P.Ya., 1992. Possible regional climate consequences of the Pinatubo eruption: an empirical approach. Geophysical Research Letters 19 15., 1603-1606.

Hammer, C.U., 1977. Past volcanism revealed by Greenland ice sheet impurities. Nature 270, 482-486.

Hammer, C.H., 1984. Traces of Icelandic eruptions in the Greenland ice sheet. Jo“ kull 34, 51-65.

Hammer, C.U., Clausen, H.B., Dansgaard, W., 1980. Greenland ice sheet evidence of post glacial volcanism and its climatic impact. Nature 288, 230-235.

Hammer, C.U., Clausen, H.B., Dansgaard, W., 1981. Past volcanism and climate revealed by Greenland ice cores. Journal of Volcanology and Geothermal Research 11, 3-10.

Handler, P., 1986. Sratospheric Aerosols and the indian monsoon. Journal of Geophysical Research 91_D13., 14475-14490.

Handler, P., 1989. The effect of volcanic aerosols on the global climate. Journal of Volcanology and Geothermal Research 37, 233-249.

Handler, P., Andsager, K., 1994. El Nin o, volcanism, and global climate. Human Ecology 22 _1., 37-58.

Hansen, J.E., Lacis, A.A., 1990. Sun and dust versus greenhouse gases: an assessment of their relative roles in global climate change. Nature 346, 713-719.

Harington, C.R., 1992. The Year Without a Summer. Canadian Museum of Nature, Ottawa.

Hughes, M.K., 1992. Dendroclimatic evidence from the western Himalaya. In: Bradley, R.S., Jones, P.D._Eds.., Climate since A.D. 1500. Routledge, London, pp. 415-431. Hughes, M.K., Schweingruber, F.H., Cartwright, D., Kelly, P.M., 1984. July-August temperature at Edinburgh between 1721 and 1975 from tree-ring density and width data. Nature 308, 341-344.

Jacoby, G.C., Ulan, L.D., 1982. Reconstruction of past ice conditions in a Hudson bay estuary using tree-rings. Nature 298,

637-639.

Jacoby, G.C., D’Arrigo, R., 1989. Reconstructed northern hemispere annual temperature since 1671 based on high-latitude tree-ring data from north America. Climatic Change 14, 39-59. Jacoby, G.C., D’Arrigo, R., 1992. Spatial patterns of tree-growth anomalies from the North American boreal treeline in the early 1800s, including the year 1816. In: Harington, C.R. Ed.., The Year Without a Summer? World Climate in 1816. Canadian Museum of Nature, Ottawa, pp. 255-269. Jacoby, G.C., Ivanciu, I.S., Ulan, L.D., 1985. Reconstructed summer degree-days in Central Alaska and Northwestern Canada since 1524. Quaternary Research 23, 18-26.

Jacoby, G.C., Ivanciu, I.S., Ulan, L.D., 1988. A 263-year record of summer temperature for Northern Quebec reconstructed from tree-ring data and evidence of a major climatic shift in the early 1800s. Palaeogeography, Palaeoclimatology, Palaeoecology 64, 69-78.

Jones, P.D., Bradley, R.S., 1992. Climatic variations in the longest instrumental records. In: Bradley, R.S., Jones, P.D. _Eds.., Climate Since AD 1500. Routledge, London, pp. 246-268. Kelly, P.M., Sear, C.B., 1984. Climatic impact of explosive 
volcanic eruptions. Nature 311, 740-743.

Kelly, P.M., Wigley, T.M.L., Jones, P.D., 1984. European pressure maps for 1815-16, the time of the eruption of Tambora.

Climate Monitor 13, 76-91.

Kington, J.A., 1992. Weather Patterns over Europe in 1816. In: Harington, C.R._Ed.., The Year Without a Summer. Canadian Museum of Nature, Ottawa, pp. 358-371.

Kuniholm, P.I., 1990. Archaeological evidence and non evidence for climate change. Philosophical Transactions of the Royal Society of London A 330, 645-655.

Lacis, A., Hansen, J., Sato, M., 1992. Climate forcing by stratospheric aerosols. Geophysical Research Letters 19 15., 16071610.

LaMarche, V.C., 1974. Palaeoclimatic inferences from long treering records. Science 183, 1043-1048.

LaMarche, V.C., Stockton, C.W., 1974. Chronologies from temperature sensitive bristlecone pines at upper treeline in western

United States. Tree-ring Bulletin 34, 21-45.

LaMarche, V.C., Hirschboek, K., 1984. Frost rings in trees as records of major volcanic eruptions. Nature 307, 121-126.

LaMarche, V.C., Graybill, D.A., Fritts, H.C., Rose, M.R., 1984.

Rising atmospheric $\mathrm{CO}_{2}$ : tree-ring evidence of growth enhancement

in natural vegetation. Science 225, 1019-1021.

Lamb, H.H., 1970. Volcanic dust in the atmosphere; with a

chronology and assessment of its meteorological significance.

Philosophical Transactions of the Royal Society of London A

266_1170., 425-533.

Lamb, H.H., 1992. First essay at reconstructing the general atmospheric circulation in 1816 and the Early Nineteenth Century.

In: Harington, C.R._Ed.., The Year Without a Summer.

Canadian Museum of Nature, Ottawa, pp. 355-357.

Landsberg, H.E., Albert, J.M., 1974. The summer of 1816 and

volcanism. Weatherwise 27 2., 63-66.

Lary, D.J., Balluch, M., Bekki, S., 1994. Solar heating rates after a volcanic eruption: The importance of SO2 absorption. Quarterly Journal of the Royal Meteorological Society 120, 16831688.

Lotter, A.F., Birks, H.J.B., 1993. The impact of the Laacher See Tephra on terrestrial and aquatic ecosystems in the Black Forest, southern Germany. Journal of Quaternary Science 8 3., 263-276.

Lough, J.M., 1992. Climate in 1816 and 1811-20 as reconstructed from western North American Tree-Ring Chronologies. In: Harington, C.R._Ed.., The Year Without a Summer. Canadian Museum of Nature, Ottawa, pp. 97-114.

Manley, G., 1974. Central England temperatures: monthly means 1659 to 1973 . Quarterly Journal of the Royal Meteorological Society 100, 389-405.

Mass, C., Schneider, S.H., 1977. Statistical evidence on the influence of sunspots and volcanic dust on long term temperature records. Journal of Atmospheric Science 34, 1995-2008.

Mass, C.F., Portman, D.A., 1989. Major volcanic eruptions and climate: a critical evaluation. Journal of Climate 2, 566-593. Mayewski, P.A., Meeker, L.D., Morrison, M.C., Twickler, M.S., Whitlow, S.I., Ferland, K.K., Meese, D.A., Legrand, M.R., Steffensen, J.P., 1993. Greenland ice core 'signal' characteristics: an expanded view of climate change. Journal of Geophysical Research 98 _12., 839-848.

Meko, D.M., 1992. Dendroclimatic evidence from the Great Plains of the United States. In: Bradley, R.S., Jones, P.D._Eds.., Climate since A.D. 1500. Routledge, London, pp. 312-330. McClelland, L., Simkin, T., Summers, M., Nielsen, E., Stein, T.C., 1989. Global Volcanism 1975-1985. Prentice Hall, New Jersey.

McCormick, M.P., Thomason, L.W., Trepte, C.R., 1995. Atmospheric effects of the Mt Pinatubo eruption. Nature 373, 399-404.

Mosley-Thompson, E., 1992. Paleoenvironmental conditions in antarctica since A.D.1500: ice core evidence. In: Bradley, R.S., Jones, P.D._Eds.., Climate Since AD 1500. Routledge,
London, pp. 572-591.

Mossman, R.C., 1896. The meteorology of Edinburgh. Transactions of the Royal Society of Edinburgh 39, 63-207.

Nesje, A., Johannessen, T., 1992. What were the primary forcing mechanisms of high-frequency Holocene climate and glacier variations. The Holocene 2 1., 79-84.

Neumann, J., 1990. The 1810s in the Baltic region, 1816 in particular: air temperatures, grain supply and Mortality. Climatic Change 17 1., 97-120.

Newhall, G.C., Self, S., 1982. The volcanic explosivity index _VEI.: an estimate of explosive magnitude for historical volcanism. Journal of Geophysical Research 87_C2., 1231-1238. Nicholls, N., 1988. Low latitude volcanic eruptions and the El Nin o Southern oscillation. Journal of Climatology 8, 91-95. Nicholls, N., 1990. Low latitude volcanic eruptions and the El Nin o Southern oscillation: A reply. International Journal of Climatology 10, 425-429.

Oswalt, W.H., 1957. Volcanic activity and Alaskan Spruce growth in AD1783. Science 126, 928-929.

Palais, J.M., Sigurdsson, H., 1989. Petrologic evidence of volatile emissions from major historic and pre-historic volcanic eruptions. Berger, A., Dickinson, R.E., Kidson, J.W._Eds.., Understanding Climate Change: Geophysical Monograph 52 _ 7., 31-53, IUGG.

Pang, K.D., Slavin, J.A., Chou, H., 1987. Climatic anomalies of the late third century B.C.; correlation with volcanism, solar activity and planetary alignment. Eos 68, 1234.

Pang, K.D., Srivastava, S.K., Chou, H., 1988. Climatic impacts of past volcanic eruptions: inferences from ice-core, tree-ring and historical data. Eos 69, 1062.

Pang, K.D., Keston, R., Srivastava, S.K., Chou, H., 1989. Climatic and hydrologic extremes in early chinese history: possible causes and dates. Eos 70, 1095.

Parker, D.E., 1985. Frost rings in trees and volcanic eruptions. Nature 313, 160-161.

Peel, D.A., 1992. Ice core evidence from the Antarctic Peninsula region. In: Bradley, R.S., Jones, P.D._Eds.., Climate Since AD 1500. Routledge, London, pp. 549-571.

Petit, J.R., Mounier, L., Jouzel, J., Korotkevich, Y.S., Kotlyakov, V.I., Lorius, C., 1990. Palaeoclimatological and chronological implications of the Vostock ice core. Nature 343, 56-58.

Pfister, C., 1992. The year without a summer in Switzerland:1628 and 1816. In: Harington, C.R._Ed.., The Year Without a Summer. Canadian Museum of Nature, Ottawa, pp. 416-417. Pinto, J.P., Turco, R.P., Toon, O.B., 1989. Self-limiting physical and chemical effects in volcanic eruption clouds. Journal of Geophysical Research-Atmospheres 94_ND8., 11165-11174. Pollack, J.B., 1981. Measurements of the volcanic plumes of Mt. St. Helens in the stratosphere and troposphere: Introduction. Science 211, 815-816.

Porter, S.C., 1981. Recent glacier variations and volcanic eruptions. Nature 291, 139-141.

Porter, S.C., 1986. Pattern and Forcing of Northern Hemisphere Glacier Variation during the Last Millennium. Quaternary Research 26, 27-48.

Post, J.D., 1977. The Last Great Subsistence Crisis of the Western World. John Hopkins Univ. Press.

Pyle, D.M., 1992. On the 'Climatic Effectiveness' of volcanic eruptions. Quaternary Research 37, 125-129.

Pyle, D.M., Beattie, P., Bekki, S., Pyle, J., 1997. Volcanic sulphur budgets and the impact of large magnitude explosive eruptions. Quarterly Journal of the Royal Geological Society.

Rampino, M.R., 1988. Volcanic winters. Annual Review of Earth and Planetary Science 16, 73-99.

Rampino, M.R., Self, S., 1982. Historic eruptions of Tambora

_1815., Krakatau_1883., and Agung_1963., their stratospheric aerosols and climatic impact. Quaternary Research 18, 127143.

Rampino, M.R., Self, S., 1984. Sulphur rich volcanic eruptions and stratospheric aerosols. Nature 310, 677-679. 
Rampino, M.R., Self, S., Fairbridge, I.W., 1982. Can rapid climate change cause volcanic eruptions? Science 206, 826-829.

Renfrew, C., 1979. The Eruption of Thera and Minoan Crete.

Volcanic Activity and Human Ecology. Academic Press, London. Robock, A., Mao, J., 1992. Winter warming from large volcanic eruptions. Geophysical Research Letters 12 _24., 2405-2508. Robock, A., Mao, J., 1995. The volcanic signal in surface temperature observations. Journal of Climate 8, 1086-1103.

Sato, M., Hansen, J.E., McCormick, M.P., Pollack, J.B., 1993.

Stratospheric aerosol optical depths, 1850-1990. Journal of

Geophysical Research-Atmospheres 98_D12., 22987-22994.

Schove, D.J., 1950. Tree-rings and summer temperatures. Scottish

Geographical Magazine 66 _1., 37-42.

Schove, D., 1954. Summer temperatures and Tree rings in Northern

Scandinavia. Geografiska Annaler 36, 40-80.

Scuderi, L.A., 1990. Tree-ring evidence for climatically effective

volcanic eruptions. Quaternary Research 34, 67-85.

Scuderi, L.A., 1992. Climatically effective volcanism. Quaternary

Research 37, 130-135.

Sear, C.B., Kelly, P.M., Jones, P.D., Goodess, C.M., 1987. Global

surface temperature responses to major volcanic eruptions.

Nature 330, 365-367.

Self, S., Rampino, M.R., Barbera, J.J., 1981. The possible effects of large 19th and 20th century volcanic eruptions on zonal and hemispheric surface temperatures. Journal of Volcanology and Geothermal Research 11, 41-60.

Sigurdsson, H., 1990. Evidence of volcanic loading of the atmosphere and climatic response. Global and Planetary Change 3

3., 277-290.

Simkin, T., Siebert, L., McClelland, L., Bridge, D., Newhall, C., Latter, J.H., 1981. Volcanoes of the World. Hutchinson Ross, Strandsburg, PA.

Smith, D.C., Borns, H.W., Baron, W.R., Bridges, A.E., 1981.

Climatic stress and Maine agriculture. In: Wigley, T.M.L.,

Ingram, M.J., Farmer, G. Eds.., Climate and history: studies

in past climates and their impact on man, pp. 451-464, C.U.P.

Stommel, H., Stommel, E., 1979. The year without a summer.

Scientific American 240 6., 134-140.

Stommel, H., Stommel, E., 1983. Volcano weather. The story of

1816, the year without a summer. Seven Seas, Newport.

Stothers, R.B., Rampino, M.R., 1983a. Historic volcanism, european dry fogs and Greenland ice precipitation. 1500 B.C.-A.D.

1500. Science 222, 411-413.

Stothers, R.B., Rampino, M.R., 1983b. Volcanic eruptions in the mediterranean before A.D.630 from written and archaeologcal sources. Journal of Geophysical Research 88_B8., 6357-6371. Stuiver, M., Braziunas, T.F., 1992. Evidence of solar variations. In: Bradley, R., Jones, P.D._Eds.., Climate since A.D. 1500.

Routledge, London, pp. 593-602.

Tarussov, A., 1992. The Arctic from Svalbard to Severnaya Zemlya: climatic reconstructions from ice cores. In: Bradley, R.S., Jones, P.D._Eds.., Climate Since AD 1500. Routledge, London, pp. 483-504.

Thompson, L.G., 1992. Ice core evidence from Peru and China. In: Bradley, R.S., Jones, P.D._Eds.., Climate since AD 1500. Routledge, London, pp. 517-548.

Villalba, R., 1990. Climatic fluctuations in Northern Patagonia during the last 1000 years as inferred from tree-ring records.

Quaternary Research 34, 346-360.

Warner, R., 1990. The 'Prehistoric' Irish annals: fable or history?.

Archaeology Ireland 4 _1., 30-33.

White, R.S., Humphreys, C.J., 1994. Famines and cataclysmic

volcanism. Geology Today, 181-185, September-October.

Wigley, T.M.L., 1991. Climate variability on the 10-100 year

time scale: observations and possible causes. In: Bradley, R.S.

_Ed.., Global Changes in the Past. University Corporation for

Atmospheric Research, Boulder, CO, pp. 83-101.

Wood, J.D., 1965. The complicity of climate in the 1816 depression in Dumfriesshire. Scottish Geographical Magazine 81,

5-17.
Wu, X.D., 1992. Dendroclimatic studies in China. In: Bradley, R.S., Jones, P.D._Eds.., Climate since A.D. 1500. Routledge, London, pp. 432-445.

Zielinski, G.A., Mayewski, P.A., Meeker, L.D., Whitlow, S., Twickler, M.S., Morrison, M., Meese, D.A., Gow, A.J., Alley, R.B., 1994. Record of volcanism since $7000 \mathrm{BC}$ from the GISP2 Greenland ice core and implication for the volcanoclimate system. Science 264, 948-952.

Zielinski, G.A., Germani, M.S., Larsen, G., Baillie, M.G.L., Whitlow, S., Twickler, M.S., Taylor, K., 1995. Evidence of the Eldgja_Iceland.eruption in the GISP2 Greenland ice core: relationship to eruption processes and climatic conditions in the tenth century. The Holocene 5 _2., 129-140. 